JURNAL KEPENDUDUKAN INDONESIA

p-ISSN : 1907-2902 (Print)

e-ISSN : 2502-8537 (Online)

\title{
FERTILITAS REMAJA DI INDONESIA: \\ HUBUNGAN ANTARA MELAHIRKAN PADA USIA REMAJA \\ DAN CAPAIAN PENDIDIKAN WANITA
}

\section{(ADOLESCENT FERTILITY IN INDONESIA: RELATION BETWEEN TEENAGE CHILDBEARING AND WOMEN EDUCATIONAL ATTAINMENT)}

\author{
Ari Purbowati \\ Badan Pusat Statistik
}

Korespondensi: purbowati.ari@gmail.com

\begin{abstract}
Adolescent fertility has become concerns at both national and international levels. The government of Indonesia views pregnancy and teenage childbearing as a problem that must be overcome. Giving birth in adolescence can lead to low levels of education. The aim of this study is to examine the relationship between adolescent fertility which is teenage childbearing and women's educational attainment in Indonesia. The data source used is the Indonesia Demographic and Health Survey (IDHS) 2017. Based on IDHS 2017, among women who have given birth. Around $31.5 \%$ of women gave birth for the first time before the age of 20. Of those, $3.8 \%$ gave birth out of wedlock, and $9.8 \%$ gave birth after postconception marriage. By using the instrumental variable (IV) method, the results of the study show that there is a negative association between giving birth in adolescent and women's educational attainment. After controlling for individual and community/environmental characteristics, women who experienced first birth during their adolescence have 3.5 years of education lower than women who give birth for the first time at the age of 20 years and above.
\end{abstract}

Keywords: adolescent fertility, educational attainment, years of schooling, teenage childbearing

\begin{abstract}
Abstrak
Fertilitas remaja menjadi isu yang menjadi perhatian baik di tingkat nasional maupun internasional. Pemerintah masih melihat kehamilan dan melahirkan pada usia remaja sebagai suatu permasalahan yang harus diatasi. Melahirkan pada usia remaja dapat mengarah pada rendahnya tingkat pendidikan. Penelitian ini bertujuan untuk melihat hubungan antara fertilitas remaja - dalam hal ini adalah melahirkan pada usia remaja - dengan capaian pendidikan wanita di Indonesia. Berdasarkan data SDKI 2017, sekitar 31,5\% wanita yang memiliki anak lahir hidup melahirkan pertama kali pada usia remaja yaitu di bawah 20 tahun. Dari kelompok penduduk tersebut, 3,8\% melahirkan di luar nikah, serta 9,8\% hamil di luar nikah dan melahirkan dalam ikatan perkawinan. Dengan menggunakan metode instrumental variabel (IV), hasil penelitian menunjukkan bahwa melahirkan pada usia remaja memiliki hubungan negatif terhadap lama pendidikan wanita. Setelah dikontrol dengan karakteristik individu dan komunitas/lingkungan, wanita yang melahirkan pertama kali pada usia remaja mempunyai lama pendidikan 3,5 tahun lebih rendah daripada wanita yang melahirkan pertama kali pada usia 20 tahun ke atas.
\end{abstract}

Kata Kunci: fertilitas remaja, capaian pendidikan, lama sekolah, melahirkan usia remaja 
Jurnal Kependudukan Indonesia | Vol. 14, No. 2, Desember 2019 | 153-164

\section{PENDAHULUAN}

Pembangunan berkelanjutan atau Sustainable Development Goals (SDGs) tahun 2030 telah menjadikan remaja sebagai salah satu target dalam programnya. Target yang dimaksud adalah target 3.7 yaitu jaminan akses universal terhadap layanan kesehatan seksual dan reproduksi, termasuk keluarga berencana, informasi dan pendidikan, dan integrasi kesehatan reproduksi ke dalam strategi dan program nasional pada tahun 2030 (UNSD, 2019).

Usaha pencapaian target ini menghadapi tantangan ketika permasalahan fertilitas remaja menjadi isu kependudukan, baik di tingkat nasional maupun internasional. Pada tingkat nasional, fertilitas remaja masih dilihat sebagai suatu permasalahan yang harus diatasi oleh pemangku kebijakan. Beberapa program yang digulirkan untuk mengatasi kondisi ini, antara lain peningkatan pengetahuan dan pemahaman remaja mengenai kesehatan reproduksi melalui kurikulum pendidikan di sekolah. Selain itu, perluasan akses ke tingkat pendidikan formal yang lebih tinggi dan penyediaan pelatihan usaha ekonomi kreatif bagi remaja wanita di daerah perdesaan juga dilakukan. Program lain yang juga dilakukan adalah peningkatan pelayanan kesehatan reproduksi pada remaja dan peningkatan layanan KB bagi pasangan usia muda seperti yang tertuang dalam Rencana Pembangunan Jangka Menengah Nasional (RPJMN) 2015-2019 (Raharja, 2014; Kementerian PPN/Bappenas, 2014).

Pada tingkat internasional, fertilitas remaja menjadi permasalahan, baik di negara miskin, berkembang, maupun negara kaya (Sánchez-Páez \& Ortega, 2018; WHO, 2018). Penduduk dunia usia remaja (10-19 tahun) pada tahun 2016 mencapai 1,2 miliar remaja (US Census Bureau, 2017) dan diproyeksikan akan terus meningkat. Kondisi ini juga diperkirakan diikuti oleh peningkatan jumlah wanita yang melahirkan pada usia remaja dan akan mencapai lebih dari 19 juta wanita pada tahun 2035 (UNFPA, 2016).

Secara global, sekitar 16 juta wanita umur 15-19 tahun melahirkan setiap tahunnya (UNFPA, 2015). Angka tersebut berkontribusi sekitar $11 \%$ dari semua kelahiran di dunia (WHO, 2018). Di Indonesia sendiri, persentase wanita umur 15-19 tahun yang melahirkan pertama kali pada usia remaja (kurang dari 20 tahun) berfluktuatif dari tahun ke tahun. Selama lima tahun ke belakang, persentasenya menurun dari 9,5 pada tahun 2012 menjadi 7,3 pada tahun 2017 (BKKBN, BPS, Kementerian Kesehatan, \& USAID, 2013; BKKBN, BPS, dan Kementerian Kesehatan, 2018).

Gambar 1. Persentase wanita umur 15-19 tahun yang melahirkan dan hamil pertama kali pada umur kurang dari 20 tahun (usia remaja)

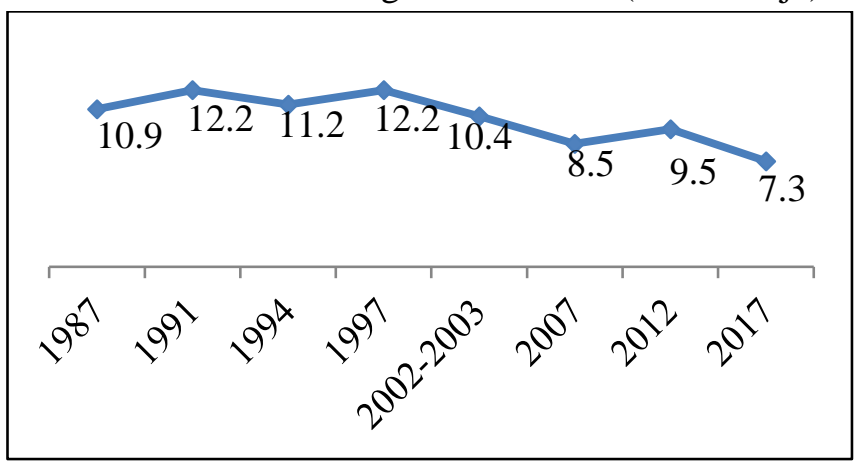

Sumber: BKKBN, BPS, Kementerian Kesehatan, \& USAID (2013); BKKBN, BPS, \& Kementerian Kesehatan (2018)

Melahirkan pada usia remaja dapat membawa dampak yang kurang menguntungkan bagi wanita. Melahirkan saat remaja dapat mengarah pada kemiskinan, rendahnya pendidikan dan kesempatan pekerjaan (WHO, 2018). McQueston dkk. (2012) mengemukakan bahwa melahirkan pada saat remaja dapat mengarah ke kondisi sosial ekonomi yang kurang baik, seperti putus sekolah, hilangnya produktivitas, dan transmisi kemiskinan antargenerasi. Selain itu, komplikasi yang terjadi selama kehamilan dan kelahiran merupakan penyebab utama kematian wanita 15-19 tahun (WHO, 2018). Namun, beberapa remaja menganggap melahirkan pada usia remaja adalah sesuatu yang direncanakan. Wanita muda dihadapkan pada tekanan untuk segera menikah dan mempunyai anak. Pada kalangan tertentu terdapat stigma sosial yang menganggap perkawinan yang dilakukan setelah melewati masa pubertas dianggap sebagai aib (Fadlyana \& Larasati, 2009).

Melahirkan pada usia remaja juga berhubungan dengan capaian pendidikan wanita. Dengan menggunakan data National Longitudinal Survey of Youth (NLSY), Klepinger dkk. (1995) menemukan bahwa melahirkan anak pada umur di bawah 20 tahun mengurangi capaian sekolah selama hampir 3 tahun pada ras putih, hitam dan Hispanic. Di Indonesia, belum banyak penelitian mengenai hubungan melahirkan pada saat remaja terhadap capaian pendidikan wanita. Informasi yang 
banyak tersedia adalah faktor-faktor yang memengaruhi fertilitas remaja, salah satunya pendidikan. Raharja (2014) menyatakan bahwa persentase remaja wanita dengan lama pendidikan lebih dari sembilan tahun memiliki persentase kejadian fertilitas sebesar 3\%. Sementara itu, persentase kejadian fertilitas pada wanita dengan lama pendidikan maksimal sembilan tahun lebih besar tiga kali lipat atau sebanyak $15 \%$. Mayoritas penelitian membuktikan bahwa melahirkan pada usia remaja membawa pengaruh negatif terhadap pendidikan wanita. Akan tetapi, belum ada kesepakatan mengenai besaran pengaruh tersebut. Dengan kata lain, besaran pengaruh masih berbeda-beda pada masingmasing penelitian.

Terkait dengan isu estimasi, variabel melahirkan pada usia remaja merupakan variabel endogen. Variabel endogen adalah variabel yang nilainya dipengaruhi atau ditentukan oleh variabel lain dalam model. Beberapa penelitian mengenai hubungan melahirkan pada usia remaja terhadap pendidikan memperlakukan variabel melahirkan pada usia remaja sebagai variabel eksogen (Upchurch \& McCarthy, 1990; Forste \& Tienda, 1992). Hal ini menimbulkan bias yang berpengaruh pada hasil estimasi karena perbedaan lama pendidikan antara wanita yang melahirkan pada usia remaja dan usia 20 tahun ke atas kemungkinan disebabkan oleh perbedaan yang sudah ada antara kedua kelompok wanita tersebut dibandingkan dengan hubungan sebab akibat antara melahirkan pada usia remaja dengan lama pendidikan wanita (Klepinger dkk., 1999).

Penelitian ini bertujuan untuk melihat hubungan antara melahirkan pada usia remaja dan lama pendidikan wanita di Indonesia. Masa remaja merupakan masa transisi dari anak-anak menuju dewasa, dengan kisaran umur 10-19 tahun (WHO, 1989). Pada masa ini, banyak kejadian penting seperti kesempatan, peran, dan tanggung jawab baru yang disandang oleh individu. Oleh karena itu, tnformasi mengenai seberapa besar hubungan melahirkan pada usia remaja terhadap pendidikan akan membantu pemangku kebijakan untuk fokus terhadap program penurunan kehamilan dan kelahiran pada usia remaja sehingga akan meningkatkan capaian pendidikan, bahkan taraf hidup bagi wanita. Untuk melihat hubungan melahirkan pada saat remaja terhadap lama pendidikan, penelitian ini akan menggunakan pendekatan atau metode instrumental variabel (IV) dalam rangka mengatasi potensi bias yang disebabkan endogenitas variabel
Fertilitas Remaja di Indonesia ...| Ari Purbowati

melahirkan pada usia remaja. Selain itu akan digunakan metode Ordinary Least Square (OLS) sebagai pembanding hasil estimasi. Data yang akan digunakan adalah data cross-sectional yaitu data Survei Demografi dan Kesehatan Indonesia tahun 2017. Selain itu digunakan data pendukung dari Survei Sosial Ekonomi Nasional (Susenas) dan data dari Kementerian Kesehatan (Kemenkes).

\section{LANDASAN TEORI}

Penelitian ini memodifikasi model fertilitas remaja dan investasi modal manusia yang dikenalkan oleh Klepinger dkk. (1999). Model ini tidak secara detail menggambarkan perilaku remaja, tetapi cukup untuk menggambarkan hubungan antara melahirkan pada usia remaja dan capaian pendidikan. Model ini menggambarkan bagaimana keputusan wanita muda untuk melahirkan pada saat remaja dan berinvestasi pada modal manusianya melalui pendidikan.

Wanita pada masa remaja mengalami dua tahap keputusan. Pada tahap pertama, wanita dihadapkan dengan keputusan mengenai aktivitas seksual, kontrasepsi, dan aborsi yang menentukan apakah mereka akan melahirkan pada usia remaja atau tidak. Melahirkan pada usia remaja sangat berkaitan dengan aktivitas seksual, kontrasepsi dan aborsi. Di Indonesia, aborsi tidak dilegalkan, sehingga penelitian ini tidak menyertakan aborsi dalam pembahasan. Keputusan ini akan berimplikasi ke keputusan tahap kedua.

Pada tahap kedua, wanita memutuskan bagaimana mengalokasikan waktu dan sumber dayanya tergantung pada ada tidaknya anak. Pada tahap ini, keputusan remaja wanita dalam hal pendidikan tergantung apakah mereka melahirkan dan merawat anak atau tidak melahirkan pada usia remaja. Melahirkan pada usia remaja akan menyita waktu wanita untuk fokus dan mengurus anaknya dimana waktu tersebut seharusnya dapat dia gunakan untuk belajar dan sekolah. Selain itu, norma yang ada dalam masyarakat terhadap wanita yang melahirkan pada saat remaja terutama di luar nikah berimplikasi pada stigma negatif dari masyarakat Kondisi ini dapat mengarah pada pengucilan sosial dan kemungkinan yang lebih tinggi untuk menjadi orang tua tunggal serta membatasi wanita untuk mengakses modal sosial, dalam hal ini adalah sekolah (Greene \& Merrick, 2005). 
Jurnal Kependudukan Indonesia | Vol. 14, No. 2, Desember 2019 | 153-164

\section{METODE PENELITIAN}

\section{Sumber data}

Sumber data yang digunakan adalah Survei Demografi dan Kesehatan Indonesia (SDKI) 2017. SDKI 2017 dirancang untuk dapat menyajikan estimasi pada level nasional maupun provinsi (BKKBN, BPS, \& Kementerian Kesehatan, 2018). SDKI 2017 mengumpulkan informasi mengenai rumah tangga, wanita usia subur umur 15-49 tahun, pria kawin umur 15-54 tahun, dan remaja pria umur 15-24 tahun. Informasi rumah tangga berisi tentang seluruh anggota rumah tangga dan tamu yang menginap semalam sebelum wawancara, serta keterangan tempat tinggal rumah tangga seperti sumber air minum, jenis lantai, jenis dinding, dan kepemilikan aset.

Informasi wanita usia subur umur 15-49 tahun dan pria kawin berumur 15-54 tahun mencakup karakteristik demografi, riwayat kelahiran, kontrasepsi, perkawinan, dan HIV/AIDS. Khusus bagi wanita usia subur, terdapat pula tambahan informasi terkait preferensi fertilitas. Selanjutnya, informasi remaja pria umur 15-24 tahun berisi tentang karakteristik remaja pria, pengetahuan tentang sistem reproduksi manusia, perkawinan, dan pacaran.

Unit analisis dalam penelitian ini adalah wanita umur 26-49 tahun yang pernah melahirkan. Wanita 25 tahun ke bawah dikeluarkan dari unit analisis karena ada kemungkinan individu tersebut berstatus masih bersekolah (kecuali mereka yang mendapat pendidikan tinggi) (Qin dkk., 2016). Jumlah unit analisis dalam penelitian ini adalah 30.878 orang. Informasi wanita usia subur yang diambil dari SDKI 2017 mencakup lama pendidikan, umur pertama melahirkan, umur pertama melakukan hubungan seksual, umur saat ini, status migrasi, lama pendidikan kepala rumah tangga (KRT), jenis kelamin KRT, jumlah anggota rumah tangga (ART) dalam satu rumah tangga, tipe tempat tinggal, dan indeks kesejahteraan. Penelitian ini juga menggunakan beberapa indikator per provinsi dari SDKI 2017 antara lain persentase wanita 15-17 tahun yang menggunakan alat/metode kontrasepsi semua cara (CPR) dan angka kelahiran menurut umur atau Age Specific Fertility Rate (ASFR) umur 15-19 tahun.

Selain data SDKI 2017, penelitian ini menggunakan data pendukung yang berasal dari sumber lainnya, yaitu survei Susenas (BPS) dan Kementerian Kesehatan.
Data tersebut antara lain angka partisipasi sekolah atau APS tahun 2017 menurut provinsi (Susenas), jumlah dokter, jumlah perawat dan bidan, jumlah puskesmas, dan jumlah rumah sakit tipe $\mathrm{C}$ menurut provinsi tahun 2017 yang berasal dari Kementerian Kesehatan (Kementerian Kesehatan RI, 2018).

\section{Metode empiris}

Tujuan penelitian ini adalah melihat hubungan antara melahirkan pada usia remaja dan capaian pendidikan wanita. Idealnya, data yang digunakan adalah data panel. Data yang digunakan adalah data SDKI 2017 yang merupakan data cross-section. Capaian pendidikan dalam penelitian ini digambarkan dengan lama sekolah.

Isu yang muncul dalam estimasi ini adalah adanya potensi endogenitas pada fertilitas, dalam hal ini adalah melahirkan pada saat remaja. Jika wanita mengetahui bahwa melahirkan pada usia remaja dapat memengaruhi capaian pendidikannya, maka fertilitas dapat ditentukan secara bersamaan dengan pendidikan. Untuk mengatasi adanya potensi bias tersebut, maka penelitian ini menggunakan pendekatan instrumental variabel (IV) untuk mengestimasi hubungan melahirkan pada saat remaja terhadap capaian pendidikan wanita. Metode instrumental variabel ini mengizinkan fertilitas, dalam hal ini melahirkan pada usia remaja, ditentukan secara bersamaan dengan variabel pendidikan (Klepinger dkk.,1995).

Model empiris yang digunakan dalam penelitian ini adalah

$y=\alpha_{0}+\theta f+\alpha_{2} X_{k}+\alpha_{3} X_{c}+u$

Dengan asumsi $f$ adalah variabel endogen pada persamaan (1) di mana $\operatorname{cov}(f, u) \neq 0$.

$f=\beta_{0}+\gamma Z+\beta_{1} X_{k}+\beta_{2} X_{c}+\varepsilon$

Untuk mengatasi endogenitas pada persamaan (1), digunakan variabel instrumen Z. Pada penelitian ini digunakan satu set variabel instrumen $Z$. Ada beberapa syarat yang harus dipenuhi oleh sebuah instrumen yang baik, antara lain :

a. Instrumen tidak berkorelasi dengan eror pada persamaan estimasi

$\operatorname{cov}(z, u)=0$ 
b. Instrumen relevan (memengaruhi pendidikan hanya melalui fertilitas)

$$
\operatorname{cov}(z, f) \neq 0
$$

Keterangan :

$$
\begin{aligned}
& \text { y : lama pendidikan, } \\
& \text { f : variabel fertilitas (melahirkan pada usia } \\
& \text { remaja), } \\
& \text { X_k : set atau kumpulan variabel karakteristik } \\
& \text { individu dan rumah tangga, } \\
& \text { X_c : set atau kumpulan variabel komunitas atau } \\
& \text { lingkungan, } \\
& \mathrm{Z} \quad \text { : set atau kumpulan variabel instrumen. }
\end{aligned}
$$

Untuk mendapatkan estimasi $\theta$ dengan variabel endogen f yang berbentuk dummy pada persamaan (1), penelitian ini menggunakan tahapan yang digunakan oleh Adams dkk. (2009). Tahapannya adalah :

a. Estimasi model fertilitas dengan menggunakan variabel instrumen $\boldsymbol{Z}$. Karena fertilitas merupakan variabel dummy, maka estimasi yang digunakan adalah estimasi model probit.

b. Menghitung nilai dugaan (fitted probabilities) $\hat{f}$ dari variabel fertilitas (melahirkan usia remaja).

c. Mengestimasi $\theta$ dengan menggunakan prosedur two stage least square dengan menambahkan $\hat{f}$ sebagai salah satu instrumen.

\section{Definisi operasional}

Pada penelitian ini terdapat dua variabel endogen, yaitu melahirkan pada usia remaja dan lama pendidikan. Remaja didefinisikan sebagai individu yang berumur 10 sampai 19 tahun (WHO, 2019), sehingga wanita yang melahirkan pada usia remaja didefinisikan sebagai wanita yang melahirkan anak pertama kali pada umur di bawah 20 tahun. Klepinger dkk. (1999) juga menggunakan batas umur di bawah 20 tahun untuk umur melahirkan pada usia remaja. Variabel fertilitas (melahirkan pada usia remaja) merupakan variabel dummy dengan nilai 1 untuk wanita yang melahirkan pertama kali di bawah umur 20 tahun (melahirkan pada usia remaja) dan 0 untuk lainnya (wanita yang melahirkan pertama kali saat usia 20 tahun ke atas). Sementara itu, variabel lama pendidikan dihitung dalam tahun.

Variabel eksogen terdiri dari set atau kumpulan variabel karakteristik individu dan rumah tangga dan set variabel lingkungan atau komunitas. Set variabel karakteristik
Fertilitas Remaja di Indonesia ...| Ari Purbowati

individu dan rumah tangga terdiri dari umur (tahun), status migran (1. Migran hidup, 0. Lainnya), lama sekolah Kepala Rumah Tangga (KRT), jenis kelamin KRT (1. Laki-laki, 2. Perempuan), jumlah anggota rumah tangga (ART) dalam rumah tangga, tipe tempat tinggal (1. Perkotaan, 2. Perdesaan), indeks kesejahteraan yang dibagi menjadi 4 kelompok yaitu indeks kesejahteraan 1 (1. Sangat kaya, 0. lainnya), indeks kesehajteraan 2 (1. Kaya, 0. Lainnya), Indeks kesejahteraan 3 (1. Menengah, 0. lainnya), dan Indeks kesejahteraan 4 (1. Miskin, 0. lainnya). Migran hidup pada penelitian ini adalah migran seumur hidup yaitu wanita yang provinsi tempat lahirnya berbeda dengan provinsi tempat tinggal sekarang (pada saat pencacahan). Set variabel komunitas atau lingkungan antara lain Angka Partisipasi Selolah (APS) usia 7-12, 13-15, 16-18, dan 19-24.

Salah satu variabel yang dijadikan instrumen adalah umur pertama melakukan hubungan seksual. Umur pertama kali melakukan hubungan seksual merupakan salah satu karakteristik individu yang ditengarai mempunyai pengaruh terhadap melahirkan pada saat remaja tetapi tidak mempengaruhi lama sekolah wanita. Selain umur pertama berhubungan seksual, variabel instrumen lain yang digunakan adalah persentase penduduk umur 15-19 tahun yang menggunakan kontrasepsi semua cara, jumlah dokter, perawat dan bidan, jumlah puskesmas, jumlah Rumah Sakit tipe C, dan tingkat kelahiran umur (Age Specific Fertility Rate atau ASFR) 15-19 (Klepinger dkk., 1995). Set variabel ini merupakan variabel yang sangat berkaitan dengan fertilitas. Set instrumen ini juga berkaitan dengan akses ke layanan keluarga berencana.

\section{HASIL DAN PEMBAHASAN}

Tabel 1 menyajikan statistik deskriptif variabel yang digunakan dalam penelitian ini. Di antara wanita yang pernah melahirkan anak lahir hidup, sebanyak 31,5\% wanita melahirkan pertama kali pada saat remaja (umur kurang dari 20 tahun) dan sebanyak 68,5\% melahirkan pertama kali umur 20 tahun ke atas. Rata-rata lama pendidikan wanita adalah 8,9 tahun, sedangkan wanita yang melahirkan pada usia remaja mempunyai rata-rata lama pendidikan sekitar 6,6 tahun dan wanita yang pertama kali melahirkan umur 20 tahun ke atas mempunyai rata-rata lama pendidikan 10 tahun. 
Setelah di uji dengan uji t, kedua rata-rata ini memang berbeda. Ada selisih rata-rata lama pendidikan sekitar 3,4 tahun antara wanita yang melahirkan pada saat remaja dan wanita yang melahirkan pada umur 20 tahun ke atas. Deskripsi ini konsisten dengan dugaan penelitian yaitu ada hubungan kuat dan negatif antara lama sekolah dan umur pertama kali melahirkan.

Tabel 1. Statistik Deskriptif

\begin{tabular}{|c|c|c|c|c|c|c|}
\hline \multirow[b]{2}{*}{ Variabel } & \multicolumn{2}{|c|}{ Melahirkan < 20 } & \multicolumn{2}{|c|}{ Melahirkan 20+ } & \multicolumn{2}{|c|}{ Total } \\
\hline & Mean & $\begin{array}{l}\text { Std } \\
\text { dev }\end{array}$ & Mean & $\begin{array}{l}\text { Std } \\
\text { dev }\end{array}$ & Mean & $\begin{array}{l}\text { Std } \\
\text { dev }\end{array}$ \\
\hline \multicolumn{7}{|l|}{ Variabel endogen } \\
\hline Lama sekolah (tahun) & 6,61 & 3,08 & 10,06 & 4,02 & 8,97 & 4,08 \\
\hline $\begin{array}{l}\text { Melahirkan pada usia remaja (1. Melahirkan <20, } 0 . \\
\text { Melahirkan 20+) }\end{array}$ & 31,48 & & 68,52 & & 100,00 & \\
\hline \multicolumn{7}{|l|}{ Variabel eksogen (fertilitas dan pendidikan) } \\
\hline \multicolumn{7}{|l|}{ Karakteristik individu dan rumah tangga } \\
\hline Umur (tahun) & 38,53 & 6,62 & 37,42 & 6,57 & 37,77 & 6,60 \\
\hline Status migran (1. Migran hidup, 0. Lainnya) & 27,09 & & 38,24 & & 34,73 & \\
\hline Lama sekolah KRT (tahun) & 7,27 & 5,66 & 9,46 & 5,48 & 8,77 & 5,63 \\
\hline Jenis kelamin KRT (1. Laki-laki, 2. Perempuan) & 91,21 & & 90,42 & & 90,67 & \\
\hline Jumlah ART dalam rumah tangga & 4,65 & 1,84 & 4,66 & 1,73 & 4,66 & 1,76 \\
\hline Tipe tempat tinggal (1. Perkotaan, 2. Perdesaan) & 38,85 & & 54,72 & & 49,72 & \\
\hline Indeks kesejahteraan 1 (1. Sangat kaya, 0. lainnya) & 12,25 & & 26,00 & & 21,67 & \\
\hline Indeks kesejahteraan 2 (1. Kaya, 0. lainnya) & 19,62 & & 22,39 & & 21,52 & \\
\hline Indeks kesejahteraan 3 (1. Menengah, 0. lainnya) & 21,88 & & 19,73 & & 20,41 & \\
\hline Indeks kesejahteraan 4 (1. Miskin, 0. lainnya) & 23,91 & & 17,05 & & 19,21 & \\
\hline \multicolumn{7}{|l|}{ Karakteristik komunitas atau lingkungan } \\
\hline angka partisipasi sekolah (APS) wanita 7-12 & 99,28 & 2,12 & 99,36 & 1,80 & 99,33 & 1,91 \\
\hline angka partisipasi sekolah (APS) wanita 13-15 & 95,73 & 2,43 & 96,00 & 2,21 & 95,91 & 2,28 \\
\hline angka partisipasi sekolah (APS) wanita 16-18 & 71,13 & 5,31 & 71,94 & 6,01 & 71,68 & 5,81 \\
\hline angka partisipasi sekolah (APS) wanita 19-24 & 24,70 & 4,71 & 25,25 & 5,64 & 25,08 & 5,37 \\
\hline \multicolumn{7}{|l|}{ Variabel instrumen } \\
\hline umur pertama kali berhubungan seksual (tahun) & 16,01 & 2,17 & 22,16 & 3,81 & 20,22 & 4,43 \\
\hline \% CPR wanita 15-19 (semua metode) & 46,70 & 6,19 & 46,11 & 6,34 & 46,29 & 6,30 \\
\hline Jumlah dokter & 7720 & 5173 & 7812 & 5002 & 7783 & 5057 \\
\hline Jumlah perawat dan bidan & 37536 & 22479 & 37577 & 22007 & 37564 & 22156 \\
\hline Jumlah puskesmas & 630 & 368 & 624 & 361 & 626 & 363 \\
\hline Jumlah RS tipe $\mathrm{C}$ & 12 & 9 & 12 & 9 & 12 & 9 \\
\hline ASFR 15-19 tahun & 37,39 & 11,65 & 35,63 & 11,28 & 36,18 & 11,43 \\
\hline Observasi & \multicolumn{2}{|c|}{9.719} & \multicolumn{2}{|c|}{21.159} & \multicolumn{2}{|c|}{30.878} \\
\hline
\end{tabular}

Sumber : Olah data SDKI 2017

Dari 31,5\% wanita yang melahirkan pertama kali pada usia remaja, 3,8\% diantaranya melahirkan anak pertamanya di luar ikatan perkawinan, 9,8\% hamil di luar nikah tetapi melahirkan dalam ikatan perkawinan, dan sisanya sebanyak $86,5 \%$ hamil dan melahirkan dalam ikatan perkawinan (Gambar 2). Wanita yang melahirkan pada usia remaja mempunyai rata-rata lama pendidikan lebih rendah daripada wanita yang melahirkan pada usia 20 tahun ke atas. Hal ini mendukung pernyataan bahwa wanita yang melahirkan di usia remaja cenderung tidak meneruskan pendidikannya karena terdapat prioritas lain yaitu 
menjadi ibu dan cenderung menghabiskan waktunya untuk merawat anaknya daripada belajar. Pada Gambar
3 juga dapat dilihat pola rata-rata lama pendidikan menurut status kehamilan wanita.

Gambar 2. Persentase wanita menurut status melahirkan dan status kelahiran

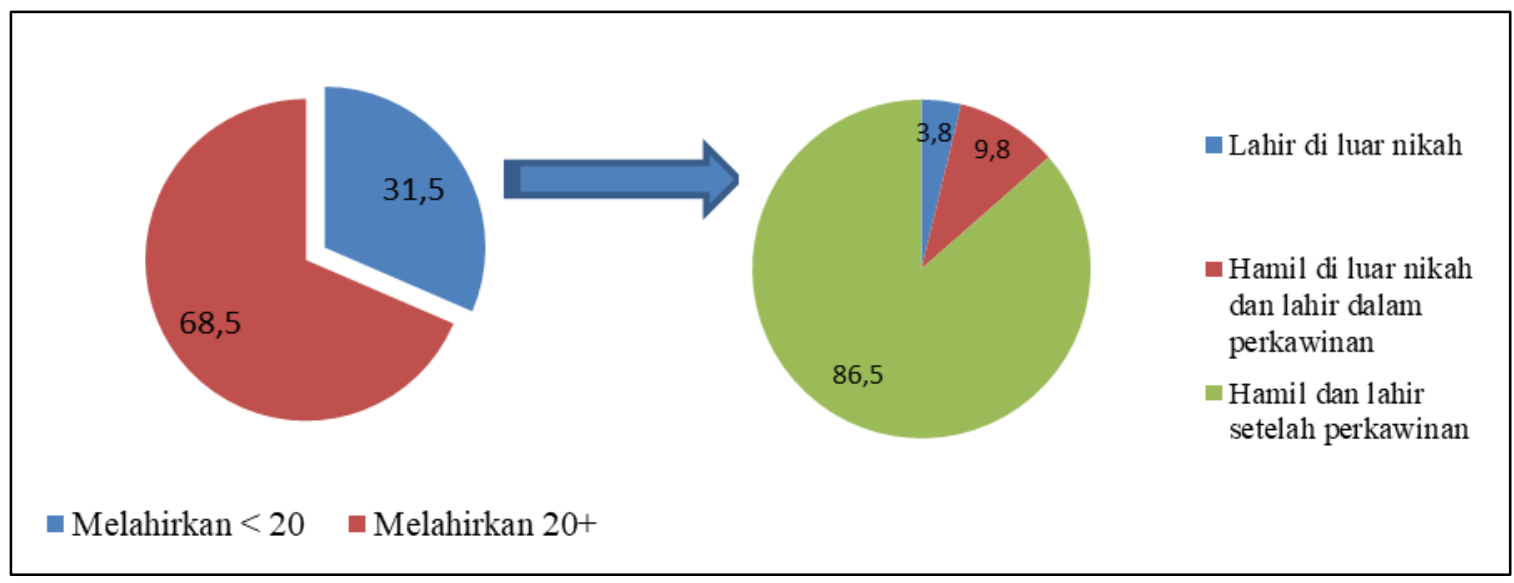

Sumber : Olah data SDKI 2017

Gambar 3. Perbandingan rata-rata lama pendidikan antara wanita yang melahirkan kurang dan lebih dari umur 20 tahun menurut status kehamilan

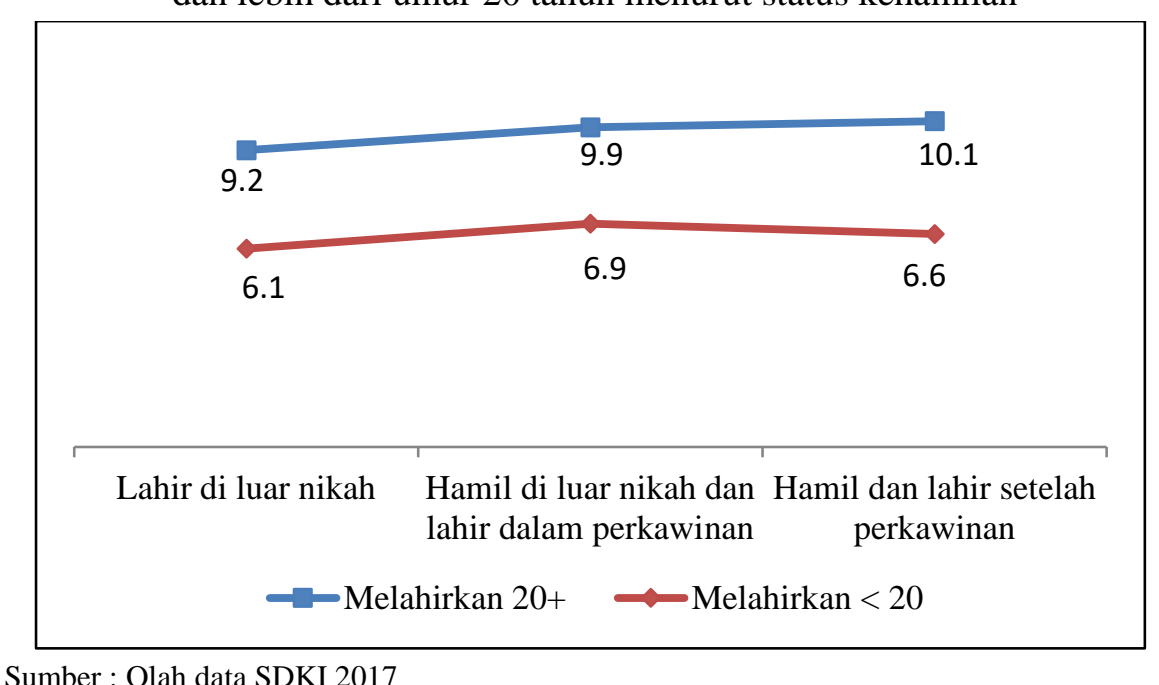

Mayoritas wanita yang melahirkan pada usia remaja berada pada rumah tangga miskin, sedangkan mayoritas wanita yang melahirkan pada usia 20 tahun ke atas berada pada rumah tangga sangat kaya (Gambar 4). Persentase wanita yang melahirkan pada usia di atas 20 tahun meningkat seiring meningkatnya tingkat kesejahteraan. Sebaliknya, persentase wanita yang melahirkan di usia remaja menurun seiring meningkatnya tingkat kesejahteraan.

Mayoritas wanita yang melahirkan pada usia remaja tinggal di daerah perdesaan, sedangkan mayoritas wanita yang melahirkan pada usia 20 tahun ke atas tinggal di daerah perkotaan (Gambar 5). Hal ini membuktikan bahwa di daerah perdesaan, wanita cenderung untuk menikah muda dan melahirkan pada usia remaja. Sebaliknya di daerah perkotaan, wanita cenderung akan menunda perkawinan dan mempunyai anak, sehingga persentase wanita yang melahirkan pada saat remaja cenderung lebih sedikit.

Pendidikan kepala rumah tangga (KRT) juga memiliki kaitan erat dengan perilaku melahirkan wanita. KRT yang berpendidikan tinggi cenderung mendorong anggota rumah tangganya untuk menikah dan mempunyai anak saat sudah dewasa, sebaliknya KRT yang berpendidikan rendah tidak terlalu memperhatikan perilaku fertilitas anggota rumah tangganya, karena fokus pada hal lain seperti pekerjaan. Tingkat pendidikan KRT memengaruhi cara pandang keluarga terhadap fertilitas. KRT yang berpendidikan lebih tinggi cenderung mendorong ART nya untuk tidak 
memiliki anak pada usia di bawah 20 tahun. Pada Gambar 6 terlihat mayoritas pendidikan KRT untuk wanita yang melahirkan pada saat remaja adalah tamat SD, sedangkan mayoritas pendidikan KRT untuk wanita yang melahirkan usia 20 tahun ke atas adalah tamat SLTA.

Mayoritas jumlah anak baik yang dimiliki wanita melahirkan usia remaja ataupun di atas 20 tahun adalah

Gambar 4. Status melahirkan menurut kuintil kekayaan

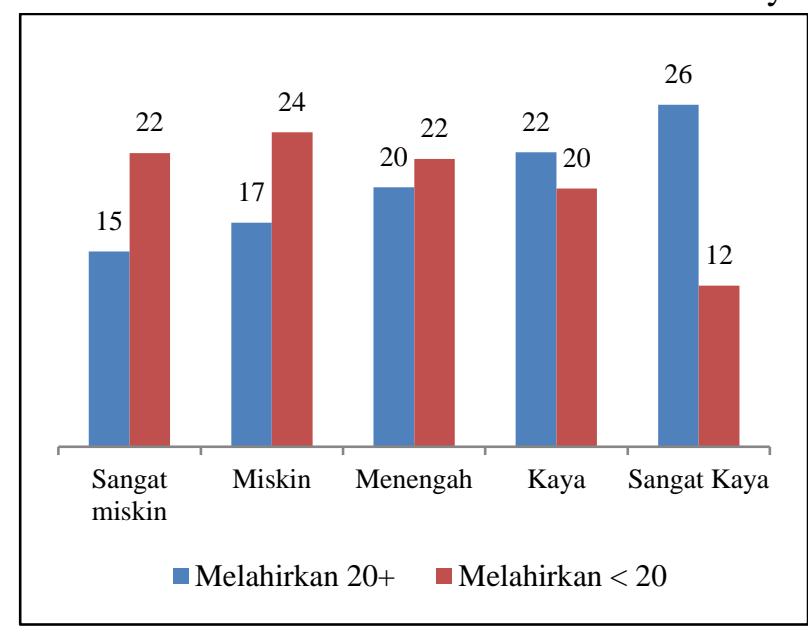

Sumber : Olah data SDKI 2017

Gambar 6. Status melahirkan menurut tingkat pendidikan KRT

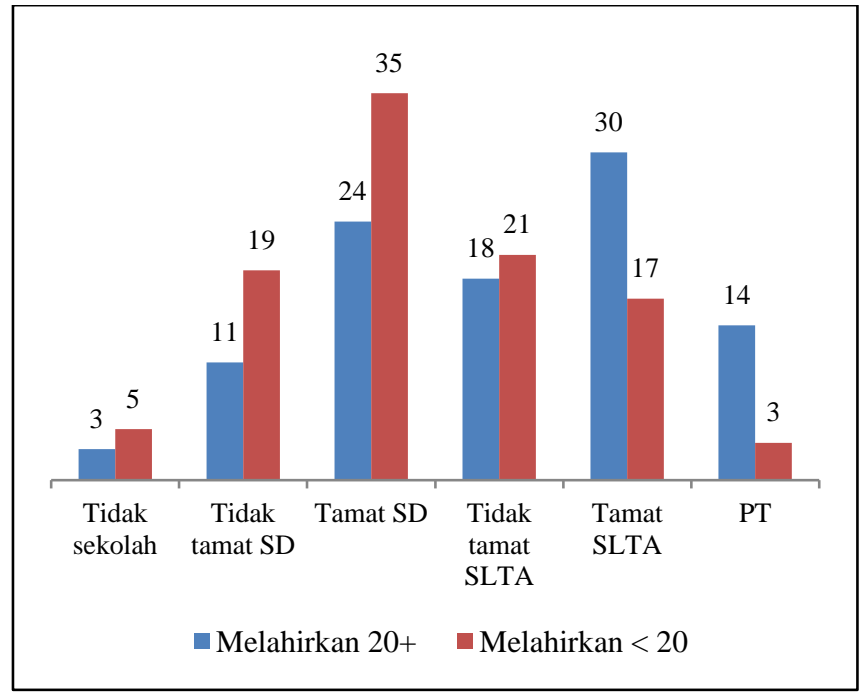

Sumber: Olah data SDKI 2017 dua orang anak (Gambar 7). Namun, wanita yang melahirkan pada saat remaja cenderung mempunyai anak lebih banyak daripada wanita yang melahirkan usia 20. Melahirkan di usia remaja akan memperpanjang masa reproduksi sehingga kecenderungan untuk memiliki anak lebih banyak menjadi lebih tinggi.

Gambar 5. Status melahirkan menurut tempat tinggal

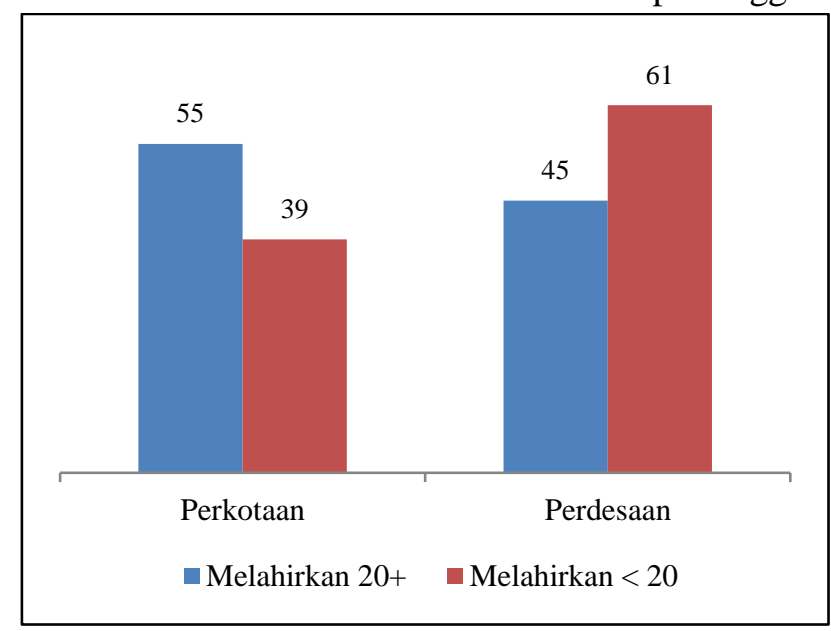

Sumber: Olah data SDKI 2017

Gambar 7. Persentase wanita menurut status melahirkan dan jumlah anak

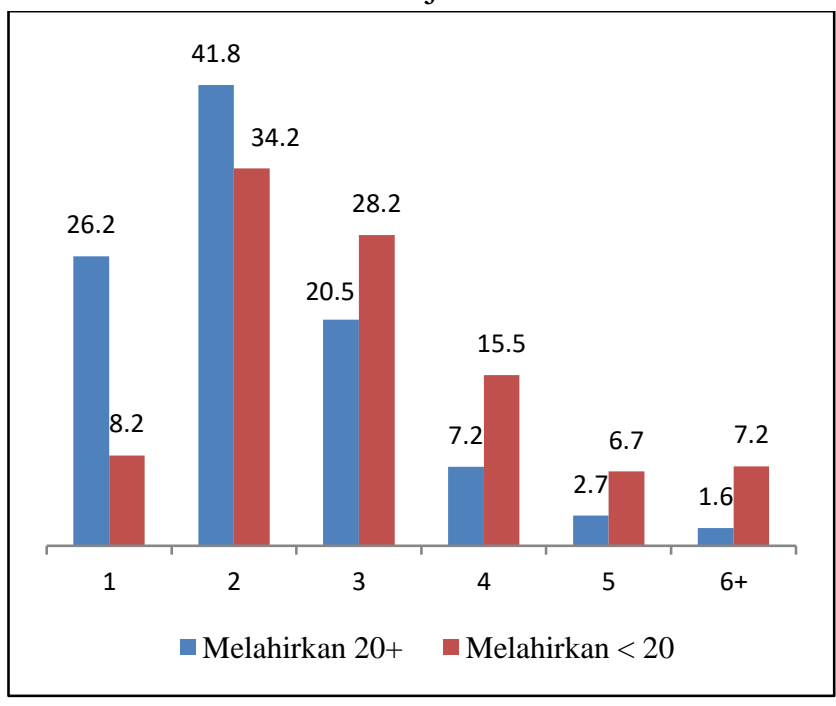

Sumber: Olah data SDKI 2017 
Tabel 2. Hasil estimasi melahirkan di usia remaja terhadap lama pendidikan

\begin{tabular}{|c|c|c|c|c|c|c|}
\hline \multirow{3}{*}{ Variabel } & \multicolumn{6}{|c|}{ Metode } \\
\hline & \multicolumn{4}{|c|}{ IV } & \multirow{2}{*}{\multicolumn{2}{|c|}{$\begin{array}{c}\text { OLS } \\
\text { Lama } \\
\text { Pendidikan }\end{array}$}} \\
\hline & \multicolumn{2}{|c|}{$\begin{array}{c}\text { Lama } \\
\text { Pendidikan }\end{array}$} & \multicolumn{2}{|c|}{$\begin{array}{c}\text { Melahirkan di } \\
\text { usia remaja }\end{array}$} & & \\
\hline Melahirkan pada usia remaja & $\begin{array}{ll}-3,514 & * * \\
(0,050) & \end{array}$ & & & & $\begin{array}{l}-2,205 \\
(0,041)\end{array}$ & $* * *$ \\
\hline Umur pertama kali berhubungan seksual & & & $\begin{array}{l}-0,458 \\
(0,005)\end{array}$ & & & \\
\hline$\%$ CPR wanita $15-19$ (semua metode) & & & $\begin{array}{l}-0,014 \\
(0,008)\end{array}$ & & & \\
\hline Jumlah dokter & & & $\begin{array}{r}-4 \mathrm{E}-05 \\
(1 \mathrm{E}-05)\end{array}$ & & & \\
\hline Jumlah perawat dan bidan & & & $\begin{array}{r}1 \mathrm{E}-05 \\
(5 \mathrm{E}-06) \\
\end{array}$ & & & \\
\hline Jumlah puskesmas & & & $\begin{array}{l}-4 \mathrm{E}-04 \\
(0,000)\end{array}$ & & & \\
\hline Jumlah RS tipe $\mathrm{C}$ & & & $\begin{array}{r}0,006 \\
(0,003)\end{array}$ & & & \\
\hline ASFR 15-19 tahun & & & $\begin{array}{r}0,004 \\
(0,002)\end{array}$ & & & \\
\hline Umur & $\begin{aligned}-0,113 \quad * * \\
(0,003)\end{aligned}$ & & & & $\begin{array}{l}-0,123 \\
(0,003) \\
\end{array}$ & $* * *$ \\
\hline Status migran & $\begin{array}{rr}0,241 & * * \\
(0,038) & \end{array}$ & $* * *$ & & & $\begin{array}{r}0,328 \\
(0,038)\end{array}$ & $* * *$ \\
\hline Lama sekolah KRT & $\begin{array}{rl}0,160 & * * \\
(0,003) & \end{array}$ & & & & $\begin{array}{r}0,169 \\
(0,003)\end{array}$ & $* * *$ \\
\hline Jenis kelamin KRT (1. Laki-laki, 2. Perempuan) & $\begin{array}{rr}0,614 & * * \\
(0,060) & \\
\end{array}$ & $* * *$ & & & $\begin{array}{r}0,676 \\
(0,061) \\
\end{array}$ & $* * *$ \\
\hline Jumlah ART dalam rumah tangga & $\begin{array}{r}0,007 \\
(0,010)\end{array}$ & & & & $\begin{array}{r}0,017 \\
(0,010) \\
\end{array}$ & \\
\hline Tipe tempat tinggal (1. Perkotaan, 2. Perdesaan) & $\begin{array}{rl}-0,209 & *: \\
(0,039) & \end{array}$ & & & & $\begin{array}{l}-0,249 \\
(0,042) \\
\end{array}$ & $* * *$ \\
\hline Indeks kesejahteraan 1 (1. Sangat kaya, 0. lainnya) & $\begin{array}{r}4,375 \\
(0,066)\end{array}$ & & & & $\begin{array}{r}4,670 \\
(0,067)\end{array}$ & $* * *$ \\
\hline Indeks kesejahteraan 2 (1. Kaya, 0. lainnya) & $\begin{array}{r}2,697 \\
(0,061)\end{array}$ & & & & $\begin{array}{r}3,019 \\
(0,062)\end{array}$ & *** \\
\hline Indeks kesejahteraan 3 (1. Menengah, 0. lainnya) & $\begin{array}{r}1,817 \quad *: \\
(0,059)\end{array}$ & $k * *$ & & & $\begin{array}{r}2,086 \\
(0,060) \\
\end{array}$ & $* * *$ \\
\hline Indeks kesejahteraan 4 (1. Miskin, 0. lainnya) & $\begin{array}{r}1,132 \\
(0,058)\end{array}$ & & & & $\begin{array}{r}1,379 \\
(0,058)\end{array}$ & $* * *$ \\
\hline Angka partisipasi sekolah (APS) wanita 7-12 & $\begin{array}{r}0,004 \\
(0,017)\end{array}$ & & & & $\begin{array}{r}0,008 \\
(0,017)\end{array}$ & \\
\hline Angka partisipasi sekolah (APS) wanita 13-15 & $\begin{array}{rr}-0,037 \\
(0,016)\end{array}$ & & & & $\begin{array}{l}-0,059 \\
(0,016) \\
\end{array}$ & $* * *$ \\
\hline Angka partisipasi sekolah (APS) wanita 16-18 & $\begin{array}{rr}0,045 & * * \\
(0,006) & \end{array}$ & & & & $\begin{array}{r}0,039 \\
(0,005) \\
\end{array}$ & $* * *$ \\
\hline Angka partisipasi sekolah (APS) wanita 19-24 & $\begin{array}{r}0,044 \quad * * \\
(0,005)\end{array}$ & & & & $\begin{array}{r}0,071 \\
(0,004) \\
\end{array}$ & $* * *$ \\
\hline Konstanta & $\begin{array}{r}9,193 \quad * * \\
(0,935)\end{array}$ & & & & $\begin{array}{l}10,371 \\
(0,927)\end{array}$ & \\
\hline$R$-square & 0.4413 & & & & 0,462 & \\
\hline Hausmant test & $1.80 \mathrm{e}+03$ & & & & & \\
\hline Observasi & & & 30.878 & & & \\
\hline
\end{tabular}

Keterangan : 1) $* * * \mathrm{p}<0.01, * * \mathrm{p}<0.05, * \mathrm{p}<0.1 .2)$ Angka dalam kurung menunjukkan standar error 
Tabel 2 menyajikan hasil estimasi melahirkan pada saat remaja terhadap lama pendidikan wanita, dengan menggunakan dua metode estimasi, yaitu metode instrumental variabel (IV) dan OLS. Hasil estimasi dengan menggunakan metode OLS digunakan sebagai pembanding hasil estimasi dengan metode IV.

Dengan metode IV, dapat dilihat bahwa melahirkan pada usia remaja berpengaruh signifikan dan negatif terhadap lama pendidikan wanita. Koefisien variabel melahirkan pada usia remaja menunjukkan angka 3,514 yang berarti bahwa wanita yang melahirkan pertama kali pada usia remaja mempunyai lama pendidikan lebih rendah sebesar 3,514 tahun dibandingkan dengan wanita yang melahirkan pertama kali pada usia 20 tahun ke atas, ceteris paribus. Hal tersebut sejalan dengan penelitian Klepinger dkk. (1995) yang menyatakan bahwa melahirkan anak pada umur di bawah 20 tahun mengurangi capaian sekolah wanita hampir 3 tahun pada ras putih, hitam dan Hispanic. Di sisi lain, hampir semua variabel kontrol berpengaruh secara signifikan terhadap lama pendidikan wanita kecuali variabel jumlah ART dalam rumah tangga dan APS umur 7-12 tahun untuk wanita.

Jika dilihat ke tahap sebelumnya pada metode IV, umur pertama kali berhubungan seksual berpengaruh secara signifikan terhadap melahirkan pada usia remaja. Semakin tua umur pertama kali berhubungan seksual, maka kecenderungan untuk melahirkan pada usia remaja akan menurun.

Estimasi dengan menggunakan OLS juga memberikan efek atau pengaruh yang signifikan dari variabel melahirkan pada usia remaja terhadap lama pendidikan wanita. Melahirkan pada usia remaja berpengaruh secara signifikan dan negatif terhadap lama pendidikan wanita, ceteris paribus. Namun, besaran koefisien variabel melahirkan pada usia remaja yang dihasilkan pada metode OLS lebih rendah dibanding koefisien melahirkan pada usia remaja yang dihasilkan pada metode IV. Koefisien melahirkan pada usia remaja dengan metode OLS adalah sebesar 2,205. Artinya, wanita yang melahirkan pertama kali pada usia remaja mempunyai lama pendidikan lebih rendah 2,205 tahun dibanding wanita yang melahirkan pertama kali pada usia 20 tahun ke atas, ceteris paribus.

Hal ini sejalan dengan penelitian Klepinger dkk. (1999) dan Angrist dan Evans (1996) yang menemukan bahwa hasil estimasi metode OLS juga menghasilkan koefisien yang lebih rendah daripada koefisien hasil estimasi dengan metode IV. Klepinger dkk. (1999) menjelaskan bahwa pola ini sebenarnya bukan pola yang diharapkan. Hasil estimasi dengan metode OLS seharusnya menghasilkan koefisien yang lebih tinggi daripada koefisien yang dihasilkan oleh metode IV karena melahirkan pada usia remaja dan capaian pendidikan merupakan keputusan yang diambil secara bersamaan atau dipengaruhi oleh karakteristik yang tidak dapat diobservasi (unobserved characteristics) sehingga hasil estimasi dengan metode OLS menghasilkan koefisien (pengaruh) yang lebih tinggi dari variabel melahirkan pada usia remaja terhadap capaian pendidikan. Hasil estimasi dengan menggunakan metode IV lebih tinggi karena metode tersebut dapat mengatasi bias yang disebabkan oleh endogenitas variabel melahirkan pada usia remaja pada metode OLS. Pengaruh variabel melahirkan pada usia remaja terhadap capaian pendidikan juga dipengaruhi oleh variasi variabel instrumen. Beberapa variabel instrumen berkaitan dengan akses ke layanan keluarga berencana. Wanita yang melahirkan pada usia remaja yang sulit memiliki akses ke pelayanan keluarga berencana mempunyai kehilangan lama pendidikan lebih tinggi daripada ratarata wanita yang melahirkan pada usia remaja.

Sementara itu, Angrist dan Evans (1996) berpendapat bahwa hasil estimasi dengan metode IV lebih tinggi daripada metode OLS karena meskipun hasil estimasi metode OLS mempunyai interpretasi sebab akibat, estimator IV dan OLS tidak mengestimasi parameter yang sama. Jika variabel melahirkan pada usia remaja bersifat heterogen, maka metode OLS menggambarkan rata-rata varian tertimbang dari variabel melahirkan pada usia remaja sementara metode IV menggambarkan pengaruh variabel melahirkan pada usia remaja bagi wanita yang capaian pendidikannya berubah melalui instrumen. Dengan kata lain, hasil estimasi dengan metode IV lebih tinggi daripada metode OLS karena variabilitas sampel pada pengaruh fertilitas terhadap pendidikan.

Pada metode IV, dilakukan pula uji Wu-Hausman untuk mengetahui endogenitas variabel melahirkan pada usia remaja. Hasil uji Wu-Hausman menunjukkan bahwa probabilitas $(P$-value $=0.00000)$ lebih kecil dari tingkat kesalahan, yang artinya menolak hipotesis nol bahwa variabel melahirkan pada usia remaja adalah eksogen. 
Dengan adanya endogenitas dari variabel melahirkan pada usia remaja, maka estimasi dengan menggunakan metode OLS tidak konsisten.

Terkait dengan hasil estimasi, wanita yang melahirkan pertama kali pada saat remaja memiliki kecenderungan untuk tidak melanjutkan sekolahnya karena waktu yang dimiliki terbagi antara belajar dan tanggung jawab harus merawat anak. Seperti yang telah dibahas di atas, d iantara wanita yang melahirkan pertama kali pada usia remaja, sekitar 3,8\% wanita melahirkan di luar nikah dan $9,8 \%$ wanita hamil di luar nikah. Hal ini memperkuat dugaan bahwa wanita yang melahirkan pada saat remaja cenderung memiliki beban yang lebih berat karena menjadi orang tua tunggal atau karena melewati masa kehamilan sendiri sehingga waktu untuk sekolah sudah tidak menjadi prioritas bagi mereka. Selain itu, stigma masyarakat terhadap wanita yang melahirkan atau hamil di luar nikah akan mempunyai dampak sosial bagi wanita yang akan menyebabkan mereka enggan untuk melanjutkan pendidikan.

\section{KESIMPULAN}

Penelitian ini mengestimasi hubungan antara melahirkan pada usia remaja terhadap lama pendidikan wanita. Dengan menggunakan metode IV dan OLS menunjukkan hal yang sama yaitu melahirkan pada saat remaja mempunyai hubungan yang signifikan dan negatif terhadap lama pendidikan wanita. Akan tetapi besaran koefisien melahirkan pada saat remaja yang dihasilkan pada kedua metode estimasi tersebut berbeda.

Pada metode IV, lama pendidikan wanita yang melahirkan pertama kali pada usia remaja lebih rendah 3,5 tahun daripada lama pendidikan wanita yang pertama kali melahirkan pada umur 20 tahun ke atas. Sementara itu, hasil dari metode OLS menunjukkan bahwa lama pendidikan wanita yang melahirkan pertama kali pada usia remaja lebih rendah 2,2 tahun daripada lama pendidikan wanita yang pertama kali melahirkan pada umur 20 tahun ke atas.

Perbedaan hasil ini dikarenakan estimasi dengan metode OLS mengandung bias karena masalah endogenitas pada variabel melahirkan pada usia remaja. Bias ini teratasi dengan menggunakan metode IV dengan menggunakan beberapa set instrumen seperti umur pertama kali berhubungan seksual, persentase
Fertilitas Remaja di Indonesia ...| Ari Purbowati

wanita umur 15-19 tahun yang menggunakan alat/cara kontrasepsi semua metode, jumlah dokter, jumlah perawat dan bidan, jumlah puskesmas, jumlah RS Tipe C, dan ASFR 15-19 tahun. Beberapa set instrumen ini berkaitan dengan akses ke layanan keluarga berencana. Wanita yang melahirkan pada usia remaja yang sulit memiliki akses ke pelayanan keluarga berencana mempunyai kehilangan lama pendidikan lebih tinggi daripada rata-rata wanita yang melahirkan pada usia remaja.

Hasil penelitian ini akan membantu pemangku kebijakan untuk fokus terhadap penurunan kehamilan dan kelahiran pada usia remaja sehingga akan meningkatkan capaian pendidikan yang nantinya akan berdampak pada peningkatan taraf hidup dan kesempatan kerja wanita. Pemangku kebijakan dapat meningkatkan akses dan pelayanan keluarga berencana bagi remaja, khususnya wanita untuk mengurangi kehamilan diusia remaja.

\section{DAFTAR PUSTAKA}

Adams, R., Almeida, H., \& Ferreira, D. (2009). Understanding the relationship between founderCEOs and firm performance. Journal of Empirical Finance, 16(1), 136-150. https://doi.org/10.1016/j.jempfin.2008.05.002

Angrist, J. D., \& Evans, W. N. (1996). Schooling and labor market consequences of the 1970 state abortion reforms. https://www.nber.org/papers/ w5406.pdf

BKKBN, BPS, Kementerian Kesehatan, \& USAID. (2013). Survei Demografi dan Kesehatan Indonesia. BKKBN, BPS, Kementerian Kesehatan, \& USAID.

BKKBN, BPS, \& Kementerian Kesehatan. (2018). Survei Demografi dan Kesehatan Indonesia

Fadlyana, E., \& Larasati, S. (2009). Pernikahan usia dini dan permasalahannya. Sari Pediatri, 11(2), 136-140. http://dx.doi.org/10.14238/sp11.2.2009.136-41

Forste, R., \& Tienda, M. (1992). Race and ethnic variation in the schooling consequences of female adolescent sexual activity. Social Science Quarterly, 73(1), 12-30. https://www.jstor.org/stable/42862986

Greene, M. E., \& Merrick, T. (2005). Poverty reduction: Does reproductive health matter? https://openknowledge.worldbank.org/handle/10 986/13722 
Kementerian Kesehatan RI. (2018). Data dan informasi profil kesehatan Indonesia 2017. Kementerian Kesehatan.

Kementerian PPN/Bappenas (2014). Rancangan awalRencana pembangunan jangka menengah nasional 2015-2019, Buku I - Agenda Pembangunan Nasional. Kementerian PPN/Bappenas.

Klepinger, D. H., Lundberg, S., \& Plotnick, R. D. (1995). Adolescent fertility and the educational attainment of young women. Family Planning Perspectives, 27(1), 23-28. http://dx.doi.org/ $10.2307 / 2135973$

(1999). How does adolescent fertility affect the human capital and wages of young women? The Journal of Human Resources, 34(3), 421-448. http://dx.doi.org/ $10.2307 / 146375$

McQueston, K., Silverman, R., \& Glassman, A. (2012). Adolescent fertility in low- and middle-income countries: Effects and solutions. https://www.cgdev.org/sites/default/files/14261 75_file_McQueston_Silverman_Glassman_Ado lescentFertility_FINAL_0.pdf

Qin, X., Tianyu, W., \& Castiel, C. Z. (2016). Intergenerational transfer of human capital and its impact on income mobility: Evidence from China. China Economic Review, 38, 306-321. https://doi.org/10.1016/j.chieco.2014.10.005

Raharja, M. B. (2014). Fertilitas remaja di Indonesia. Kesmas National Public Health Journal, 9(1), 613. http://dx.doi.org/10.21109/kesmas.v9i1.449
Sánchez-Páez, D. A. \& Ortega, J. A. (2018). Adolescent contraceptive use and its effects on fertility. Demographic Research, 38, 1359-1388. https://www.jstor.org/stable/26457079

UNFPA. (2015). Girlhood, not motherhood: Preventing adolescent pregnancy. https://www.unfpa.org/sites/default/files/pubpdf/Girlhood_not_motherhood_final_web.pdf

UNFPA. (2016). Facing the facts : Adolescent girls and contraception.

https://www.unfpa.org/sites/default/files/resourc e-pdf/UNFPA_Adolescent_brochure.pdf

UNSD. (2019). SDG indicators. https://unstats.un.org/sdgs/indicators/Global\%20 Indicator\%20Framework\%20after\%202019\%20 refinement_Eng.pdf

Upchurch, D. M., \& McCarthy, J. (1990). The timing of a first birth and high school completion. American Sociological Review, 55(2), 224-234. https://www.jstor.org/stable/2095628

WHO. (1989). The health of youth. http://apps.who.int/iris/bitstream/handle/10665/ 172242/WHA42_TD-

2_eng.pdf?sequence $=1 \&$ isAllowed $=\mathrm{y}$

WHO. (2018). Adolescents: health risks and solutions. http://www.who.int/en/news-room/factsheets/detail/adolescents-health-risks-andsolutions

WHO. (2019). Adolescent health. https://www.who.int/southeastasia/healthtopics/adolescent-health 